\title{
Improvement of safe injection practices among nurses in Zagazig University Hospitals
}

\author{
Ghada M. Khalil \\ Public Health and Preventive Medicine, Faculty of Medicine, Zagazig University, Egypt. \\ Corresponding author: Ghada M. Khalil, Email: ghadamahmoud1@ hotmail.com
}

\begin{abstract}
:
Aim of the work: this study aimed to detect assessment of injection practice using WHO safe injection tool then implantation of education program and post intervention evaluation. Methods: this study was anon randomized intervention study performed in Zagazig University Hospitals and targeting nurses , 700 observation before and 700 observation after intervention starting by evaluation of injection practice using WHO safe injection tool then training on safe injection practice applied for nurse staff then post training evaluation of practice. Results: hand hygiene soap and alcohol rub was available in hospitals sitting in $80 \%, 85 \%$ of observation and after intervention increased up to $95 \%$ and98\% with a significant difference. Safety boxes were available for sharp disposal before intervention and become $100 \%$ available after intervention. Hospital supply $100 \%$ percent single use syringes for each patient, but the problem was for drug administration process due to deficient in cleaning of drug preparation area $88 \%$ of pre intervention observation, but practice improved to $98 \%$ after intervention with a significant difference; sharp disposal practice was improved after intervention up to $98 \%$ with significant difference. $67 \%$ of observation used non touch technique and changed to $95 \%$ after intervention with high significant difference .Vaccination coverage reached $100 \%$ after intervention and percent of nurses who received training on safe injection was $45 \%$ increased to $100 \%$ after intervention, also post needle stick injury counseling was $57 \%$ reached 100\%after intervention. Conclusions: training and education of nursing staff on safe injection practice was crucial for improvement of safe injection practice and improved both staff and patient safety.
\end{abstract}

Keywords: safe injection, needle stick, hand hygiene, sharp disposal

\section{Introduction}

Injection is a crucial health care procedure used worldwide for drug administration. Billions of injections are used worldwide for both curative care and immunization ${ }^{(\mathbf{1})}$.In developing countries, approximately 16 thousand million injections are administered a rate of 3.4 (Range 1.7-11.3) injections per person per year ${ }^{(2)}$. Majority of the injections can be replaced by oral drugs ${ }^{(2,3)}$ and are not used safely. Reuse of injection equipment without sterilization is common ${ }^{(4)}$ Unsafe injection practices which can transmit hepatitis $\mathrm{B}$, hepatitis $\mathrm{C}$, human immunodeficiency virus (HIV) and other blood borne pathogens have resulted in worldwide burden of preventable blood borne viral diseases $\left(\mathrm{BBVDs}^{(5)}\right.$. The transmitted BBVDs remain silent for many years without risk identification ${ }^{(6)}$. An injection is said to be safe if it does not harm the recipient, does not expose the provider to avoidable risk, and does not result in wastes that is dangerous for the community ${ }^{(7)}$. This is achieved by using a sterile device (Syringe, needle and cannula) for drug injection, practicing sterile technique by a qualified trained person and discarding the used devices in safe sharp container specially designed for sharp disposal. Any breach in the process makes the injection unsafe ${ }^{(1)}$.

\section{Safety of recipient}

The risk of harming recipient can be avoided by administering useful medication with a sterile single use device, and practicing proper technique by qualified and well trained health workers to ensure that safety there should be sufficient supply of single use devices throughout the year ${ }^{(8)}$.

\section{Safety of the provider}

Needle stick injury (NSI) is commonly encountered by the provider especially during recapping and it can be reduced by disposing used syringe in a puncture proof closed container immediately after use without recapping. About thirty infectious diseases 
may be transmitted by NSI, but the risk of hepatitis B infection is much higher than other infections ${ }^{(9)}$.That is why full immunization against hepatitis $\mathrm{B}$ is important to ensure safety of the provider ${ }^{(10)}$. These interventions (proper disposing technique without recapping and vaccination) can provide protection to the healthcare worker from occupational infection with blood born viral disease.

\section{Safety of the community:}

Used syringes and injection devices should be disposed safely according to local and international disposal infection control policy through incineration or grinding, unfortunately half of injection wastes through developing countries are improbably disposed and threat the communities ${ }^{(9)}$.

\section{Injection safe practice and infection control:}

Injection safety is an important component basic infection control. The concept of "standard precautions", with mandatory safe practices, must be routinely applied in all healthcare settings, and every person in working through health care sitting should be considered a potential source of infection. Best practices for injection, the collection and handling of blood samples, and waste management should be strictly followed ${ }^{(11)}$. All healthcare workers should understand and adhere to standard of safe Injection practices; that is why principles of infection control and aseptic technique need to be reinforced in training programs and incorporated into institutional polices that are monitored for adherence $^{(12) .}$ This study aimed to detect improvement of safe injection practice among nurse in zagazig university hospitals.

\section{-Objectives:}

Assessment of injection practice among nurse in Zagazig University Hospitals.
Education and training intervention program for nurses.

$$
\begin{aligned}
& \text { Post intervention evaluation for } \\
& \text { education program. }
\end{aligned}
$$

Subject and methods:

Place of study: Zigzag University (9 hospitals)

Study time:

2 weeks for observation pre intervention-15-30 September 2016, 3 months interval. OctoberNovember-December 2016

2 weeks for collection of observation post intervention.1-15 January 2017

\section{Study population:}

All nurses practice injection, the study observes practice of safe injection and counted per observation not by person.

\section{Study design:}

This was a randomized intervention study, pre and post.

Sample size and sampling technique:

Sample size wascalculated according to practice rate based on occupancy rate, 770 observations divided to 10 hospitals according to occupancy rate we used EPI-INFO program to calculate sample size.

\section{Study tool:}

WHO safe injection $\mathrm{C}$ tool revised was used to checklist preparation.

Designed on job practical training work shop for all staff worked on collecting observation at higher education council, boosters and practical training were used during education workshop.

Web based program for data entry (Higher education council web site )

\section{Analysis:}

Spss20, comparative analysis using chi square test.

\section{Research ethics:}

Verbal consent was obtained from nurses prior to study and permission for hospital administration gained prior of study. 


\section{Results}

Table 1: availability of hand hygiene supplies as mandatory for safe injection practices at 9 hospitals

\begin{tabular}{|l|l|l|l|l|l|}
\hline $\begin{array}{l}\text { Availability of hand } \\
\text { hygiene practice supplies }\end{array}$ & $\begin{array}{l}\text { Pre- } \\
\text { intervention } \\
\text { Number } \\
\text { Total 700 }\end{array}$ & $\begin{array}{l}\text { Pre- } \\
\text { intervention } \\
\text { Percent }\end{array}$ & $\begin{array}{l}\text { Post- } \\
\text { intervention } \\
\text { Number Total } \\
700\end{array}$ & $\begin{array}{l}\text { Post- } \\
\text { intervention } \\
\text { Percent }\end{array}$ & $\begin{array}{l}\text { Significant } \\
\text { Chi-square }\end{array}$ \\
\hline hand soap & 560 & $80 \%$ & 665 & $95 \%$ & 0.001 sig \\
\hline Hand drying towels & 140 & $20 \%$ & 245 & $35 \%$ & 0.001 sig \\
\hline Alcohol hand rub & 595 & $85 \%$ & 686 & $98 \%$ & 0.001 sig \\
\hline Single use latex gloves & 525 & $75 \%$ & 651 & $93 \%$ & 0.001 sig \\
\hline Safety boxes & 665 & $95 \%$ & 700 & $100 \%$ & 0.001 sig \\
\hline
\end{tabular}

Table 1:

Availability of hand hygiene supplies in hospital area were evaluated using checklist and we found that hand washing soaps was available in $80 \%$ of observation and availability increased to $95 \%$ after intervention but hand drying towels was not available except in $20 \%$ increased to $35 \%$ after intervention also alcohol hand rub was available at $85 \%$ increased to $98 \%$ after intervention single use latex gloves were present in $75 \%$ increased to $93 \%$ after intervention and safety box for sharp disposal was available in $95 \%$ increased to $100 \%$ and all previous values showed a significant difference after intervention .

Table 2:availability of safe injection tools and supplies according to patient flow

\begin{tabular}{|l|l|l|l|l|l|}
\hline $\begin{array}{l}\text { Availability of } \\
\text { safe injection } \\
\text { tools and } \\
\text { supplies }\end{array}$ & $\begin{array}{l}\text { Pre- } \\
\text { intervention } \\
\text { Number } \\
\text { Total 700 }\end{array}$ & $\begin{array}{l}\text { Pre- } \\
\text { intervention } \\
\text { Percent } \\
\text { Total 700 }\end{array}$ & $\begin{array}{l}\text { Post- } \\
\text { intervention } \\
\text { Number } \\
\text { Total 700 }\end{array}$ & $\begin{array}{l}\text { Post- } \\
\text { intervention } \\
\text { Percent } \\
\text { Total 700 }\end{array}$ & $\begin{array}{l}\text { Significant } \\
\text { Chi-square }\end{array}$ \\
\hline $\begin{array}{l}\text { Single use } \\
\text { syringes }\end{array}$ & 700 & $100 \%$ & 700 & $100 \%$ & 1 not sig \\
\hline $\begin{array}{l}\text { Single use } \\
\text { peripheral } \\
\text { catheters }\end{array}$ & 700 & $100 \%$ & 700 & $100 \%$ & 1 not sig \\
\hline $\begin{array}{l}\text { Intravenous } \\
\text { devices }\end{array}$ & 665 & $98 \%$ & 700 & $100 \%$ & 1 not sig \\
\hline $\begin{array}{l}\text { Skin } \\
\text { antiseptics }\end{array}$ & 686 & $93 \%$ & 700 & $100 \%$ & 0.001 sig \\
\hline $\begin{array}{l}\text { Plaster and } \\
\text { cotton covers }\end{array}$ & 651 & 700 & $100 \%$ & 0.001 sig \\
\hline
\end{tabular}

Single use syringes and IV catheter and devices were available in $100 \%$ of cases before and after intervention which is better than Ismail etal ${ }^{(13)}$ where there was shortage in syringe supplies reached $60 \%$.Skin antiseptic and plaster coverage after injection was available before intervention by $93 \%$ increased to $100 \%$ after intervention.Syringes, intravenous devices and peripheral catheter were available in $100 \%$ pre and post intervention sittings but plastic and cotton covers show shortage as $97 \%$ pre intervention increased to $100 \%$ after intervention. 


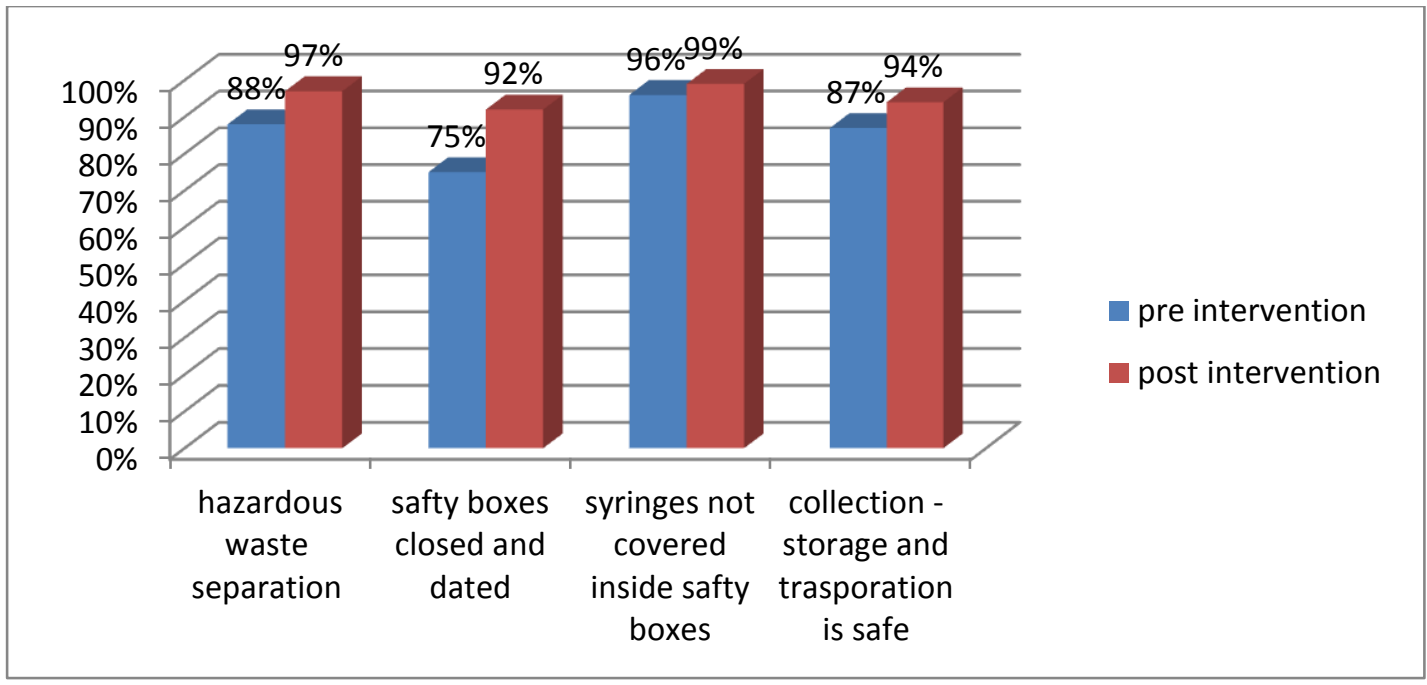

Figure 2: sharp disposal practices chart:

Fig.2 showed difference between sharp disposal practice before and after intervention which showed marked improvements in all steps specially waste separation and waste storage from $88 \%$ and $87 \%$ before intervention to $97 \%, 94 \%$ after intervention .

3- Table 3:preparation process for safe injection

\begin{tabular}{|l|l|l|l|l|l|}
\hline $\begin{array}{l}\text { Preparation } \\
\text { process for safe } \\
\text { injection }\end{array}$ & $\begin{array}{l}\text { Pre-intervention } \\
\text { Number Total } \\
700\end{array}$ & $\begin{array}{l}\text { Pre-intervention } \\
\text { Percent }\end{array}$ & $\begin{array}{l}\text { Post- } \\
\text { intervention } \\
\text { Number } \\
\text { Total 700 }\end{array}$ & $\begin{array}{l}\text { Post- } \\
\text { intervention } \\
\text { Percent }\end{array}$ & $\begin{array}{l}\text { Significant } \\
\text { Chi-square }\end{array}$ \\
\hline $\begin{array}{l}\text { Clean drug } \\
\text { preparation area }\end{array}$ & 616 & $88 \%$ & 686 & $98 \%$ & 0.001 sig \\
\hline Clean drug tray & 546 & $78 \%$ & 623 & $89 \%$ & 0.001 sig \\
\hline $\begin{array}{l}\text { Closed drug } \\
\text { vial for each } \\
\text { patient }\end{array}$ & 693 & $99 \%$ & 693 & $99 \%$ & 1 not sig \\
\hline $\begin{array}{l}\text { Closed sterile } \\
\text { syringes } \\
\text { catheter, IV } \\
\text { devices for each } \\
\text { patient }\end{array}$ & 686 & $98 \%$ & 700 & $100 \%$ & 0.001 sig \\
\hline $\begin{array}{l}\text { Disinfection of } \\
\text { drug plastic } \\
\text { cover before } \\
\text { use }\end{array}$ & 553 & $79 \%$ & 665 & $95 \%$ & 0.001 sig \\
\hline $\begin{array}{l}\text { Storage and } \\
\text { refill } \\
\text { disinfectant in } \\
\text { proper way }\end{array}$ & 455 & $65 \%$ & 630 & $90 \%$ & 0.001 sig \\
\hline
\end{tabular}

Preparation process for safe injection include many steps $1^{\text {st }}$ step was preparation for clean area for drug preparation which was $88 \%$ increased to $98 \%$ after intervention with significant difference and presence of clean drug tray was $78 \%$ increased to $89 \%$ after intervention with significant difference and uses of single syringe and catheter for each patient were $99 \%$ reached to $100 \%$ after intervention. 


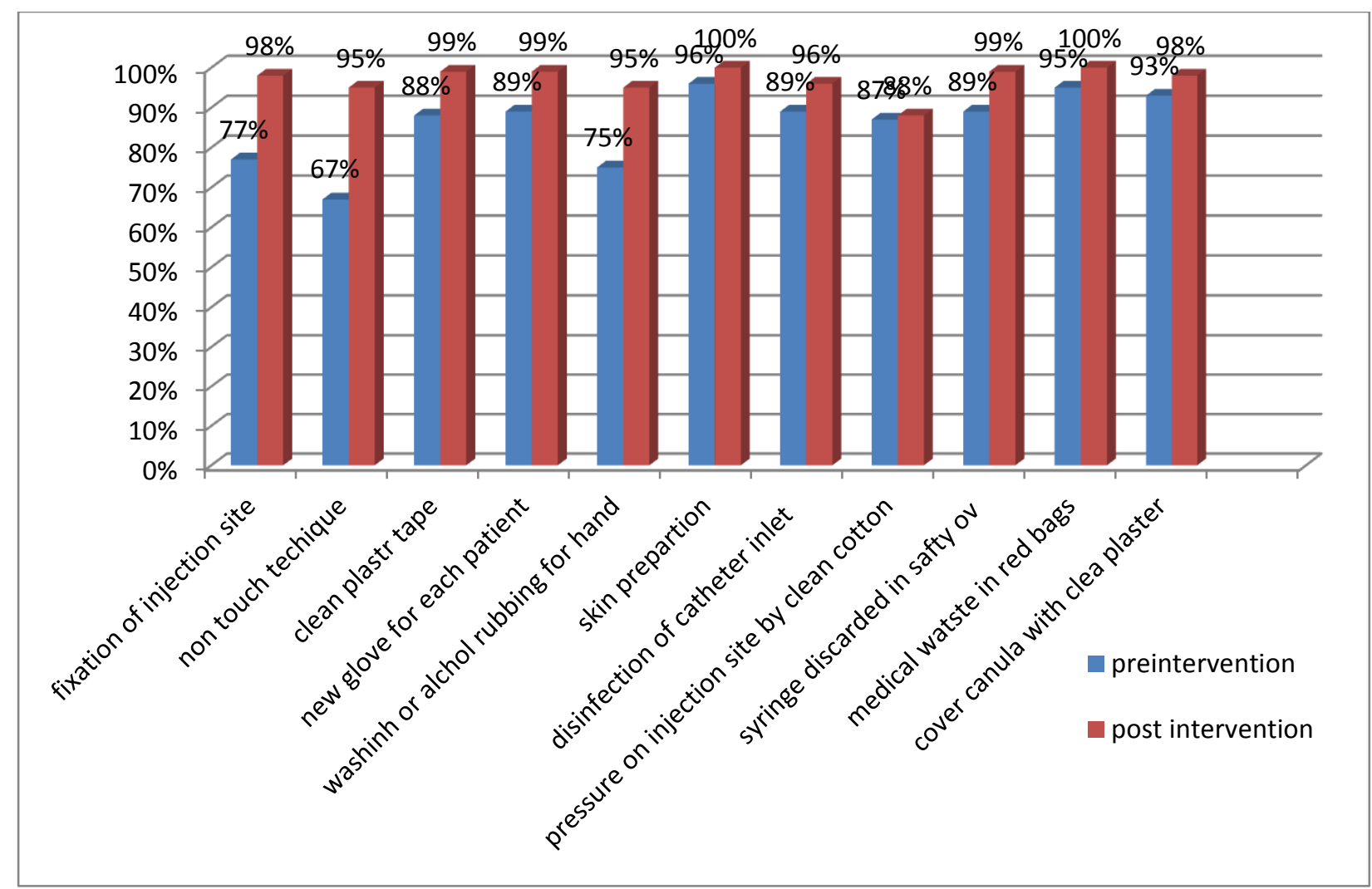

\section{Figure 3:safe injection practice steps}

This Fig. showed safe injection steps included non touch technique was performed in $67 \%$ of observation improved to $95 \%$ after intervention also washing hand or alcohol hand rubbing before injection improved to $75 \%$ to $95 \%$ after intervention with high significant difference

Table 4:staff training, education and vaccination:

\begin{tabular}{|l|l|l|l|l|l|}
\hline $\begin{array}{l}\text { Staff training } \\
\text { and } \\
\text { vaccination }\end{array}$ & $\begin{array}{l}\text { Pre- } \\
\text { intervention } \\
\text { Number Total } \\
700\end{array}$ & $\begin{array}{l}\text { Pre- } \\
\text { intervention } \\
\text { Percent }\end{array}$ & $\begin{array}{l}\text { Post- } \\
\text { intervention } \\
\text { Number } \\
\text { Total 700 }\end{array}$ & $\begin{array}{l}\text { Post- } \\
\text { intervention } \\
\text { Percent }\end{array}$ & $\begin{array}{l}\text { Significant } \\
\text { Chi-square }\end{array}$ \\
\hline $\begin{array}{l}\text { Vaccination } \\
\text { coverage }\end{array}$ & 686 & $98 \%$ & 700 & $100 \%$ & 0.001 sig \\
\hline $\begin{array}{l}\text { Training on } \\
\text { safe injection }\end{array}$ & 315 & $45 \%$ & 700 & $100 \%$ & 0.001 sig \\
\hline $\begin{array}{l}\text { Training on } \\
\text { blood born } \\
\text { pathogen }\end{array}$ & 350 & $50 \%$ & 700 & $100 \%$ & 0.001 sig \\
\hline $\begin{array}{l}\text { Needle stick } \\
\text { injury } \\
\text { notification }\end{array}$ & 623 & $89 \%$ & 700 & $100 \%$ & 0.001 sig \\
\hline $\begin{array}{l}\text { Post injury } \\
\text { counseling }\end{array}$ & 399 & $57 \%$ & 700 & $100 \%$ & 0.001 sig \\
\hline
\end{tabular}

$95 \%$ of nursing staff was vaccinated increased to $100 \%$ after intervention and $45 \%$ of nursed only received training on safe injection practice improved to $100 \%$ after intervention .only $57 \%$ of nurses perform post needle stick injury counseling before intervention improved to $100 \%$ after intervention .

Discussion

Our study involved 700 working nurses in 9 Zagazig University Hospitals according to sample size calculation based on injection rate, 
we used WHO safe injection tool as performance evaluation tool for nurse's injection practices and we used the same tool for designing intervention training materials. Availability of hand hygiene supplied as crucial step before and after safe injection practices, we found that hand soap was available for $85 \%$ study population increased to $95 \%$ after intervention with significant different, considering hand drying towels there was shortage in it up to $20 \%$ raised to $35 \%$ after intervention with significant difference and that result matched with results of Ismailet $\boldsymbol{a l} .^{(13)}$ where soap shortage reached $58 \%$ in Gharbiagovernrate , Egypt .Alcohol hand rub and single use latex gloves showed marked increase in availability percentage after intervention with asignificant difference and that result.differ extremely from Bobby etal $^{(14)}$ where latex gloves used only in $3.7 \%$ of injection practice Daly etal $^{\left({ }^{(15)}\right.}$ recorded presence of safety boxes at $75 \%$ of facilities while in our study safety boxes covered $100 \%$ of our facilities after intervention.

Considering sharps disposal practice all steps were improved up to $99 \%$ at uncovering syringes inside safety boxes that result was compared to results of Bobby etal. ${ }^{(14)}$ where sharp disposal practice was only $42 \%$.

Considering preparation practices for safe injection the most improvement taken place on cleaning practice for drug preparation area and drug tray with a significant difference before and after intervention and our result matched with those of Ismail etal $^{(13)}$.Availability of single use syringe and drug vial for each patient were not significantly changed after intervention as it were reached $99 \%$ before intervention ,the practice which showed great improvement was refilling disinfectant which changed from $65 \%$ to $90 \%$ after intervention and that is matched with results of Daly etal. $^{(15)}$. Post intervention practices showed improvements in all steps off safe injection techniques, specially: fixation of injection site . Non touch and alcohol hand rubbing before injection arematched with results of Mantaletal. ${ }^{(8)}$.

Improvement reached $100 \%$ with high significant difference in vaccination coverage and staff training on injection practice and infection control basic knowledge especially post needle stick injury notification and counseling and that result is much more satisfied than results of Mantaletal. ${ }^{(8)}$.
Conclusion:

Improvement of safe injection practices need continuous training and monitoring of staff daily practices and hospital management support by offering one use supplies is very crucial for success of improvement efforts.

\section{References}

1-World Health Organization (2011): Safety of injections Question and Answers.of the Safe Injection Global Network; Department of Essential Health Technologies. Available from:http://who.int/injection_safety/resources/ en/index.html .

2. Hutin YJ, Hauri AM, Armstrong GL(2003) :Use of injections in health care settings worldwide. BMJ.,327:1075-8.

3. Drucker E, Alcabes PG, Marx PA(2001 ) :The injection century: Massive unsterile injections and the emergence of human pathogens. Lancet ,358:89-92.

4. Kermode M, Holmes W, Langkham B, Thomas MS, Gifford S (2005):Safer injections, fewer infections: Injection safety in rural north India,. Trop Med IntHealth , 10:423-32. 5. Simonsen L, Kane A, Lloyd J, Zaffran M, Kane M(1999): Unsafe injections in the developing world and transmission of blood borne pathogen: A review. Bull World Health Organ.,77:789800.

6. Miller MA, PisaniE(1999): The cost of unsafe injection. Bull World Health Organ. ,77:808-11.

7- World Health Organization( 2012) :Programmes and projects: The SIGN alliance. Available

from: http://who.int/injection_safety/sign/en.ht $\underline{\mathrm{ml}}$.

8- Mantel C, Khamassi S, Baradel K, Nasri H, Mohsni E, Duclos P (2007): Improved safety after targeted interventions in the Syrian Arab Republic. Trop .Med.Int.Health ,12:42230.

9-World Health Organization(2008):Revised injection assessment tool (tool C- revised) Available

from:http://www.who.int/injection safety/Inje ction safety final-web.pdf .

10. Khurram M, Ijaz K, Bushra TH, Khan YN, Bhushra H, HussainW( 2012): Needle stick injuries, A survey of doctors working at tertiary care hospitals of Rawalpindi. . J Pak Med Assoc., 61:63-5. 
11-World Health Organization (2010): WHO best practices for injections and related procedures

toolkit.avaliablefrom: http://who.int/injection safety/sign/en.html

12- CDC center for disease control and prevention (2016 ): Safe Injection Practices to Prevent Transmission of Infections to Patients available from https://www.cdc.gov/hicpac/pdf/isolation/Isola tion2007.pdf,accsessed

13-Ismail N, AboulFtouh A, El Shoubary W, Mahaba H (2007): Safe injection practice among health-care workers in Gharbiya Governorate, EMHJ - Eastern Mediterranean Health Journal, 13 (4):893-906.

14-Bobby P, Sima R, Dipankar C, Sukamoli B, Raghunath M(2011): A Study on Safe Injection Practices of Nursing Personnel in a Tertiary Care Hospital of Kolkata, West Bengal, India TAF . Prev Med Bull., 10(6): 681-686

15- Daly A, Nxumalo $M$, Biellik R( 2004): An assessment of safe injection practices in health facilities in Swaziland, South African Medical Journal , 94(3): $194-197$. 